\title{
Injection of Acanthaster planci with thiosulfate-citrate-bile-sucrose agar (TCBS). I. Disease induction
}

\author{
J. A. Rivera-Posada ${ }^{1, *}$, M. Pratchett ${ }^{1}$, A. Cano-Gómez ${ }^{2,3}$, J. D. Arango-Gómez ${ }^{4}$, \\ L. Owens ${ }^{2,3}$ \\ ${ }^{1}$ ARC Centre of Excellence for Coral Reef Studies, James Cook University, Townsville, Queensland 4812, Australia \\ ${ }^{2}$ School of Veterinary and Biomedical Sciences, James Cook University, Townsville, Queensland 4812, Australia \\ ${ }^{3}$ Australian Institute of Marine Science, Townsville, Queensland 4810, Australia \\ ${ }^{4}$ School of Marine and Tropical Biology, James Cook University, Townsville, Queensland 4812, Australia
}

\begin{abstract}
This is the first report of the successful induction of a transmissible disease in the coral-eating crown-of-thorns starfish Acanthaster planci (COTS). Injection of thiosulfate-citratebile-sucrose agar (TCBS) culture medium into COTS induced a disease characterized by discoloured and necrotic skin, ulcerations, loss of body turgor, accumulation of colourless mucus on many spines especially at their tip, and loss of spines. Blisters on the dorsal integument broke through the skin surface and resulted in large, open sores that exposed the internal organs. Oedema and reddened digestive tissues and destruction of connective fibers were common. Moreover, healthy COTS in contact with these infected animals also displayed signs of disease and died within $24 \mathrm{~h}$. TCBS induced $100 \%$ mortality in injected starfish. There was no introduction of new pathogens into the marine environment. TCBS promoted the growth of COTS' naturally occurring Vibrionales to high densities with subsequent symbiont imbalance followed by disease and death.
\end{abstract}

KEY WORDS: COTS · Corallivores · Culture medium · Infectious disease · Quorum sensing · Vibrio

Resale or republication not permitted without written consent of the publisher

\section{INTRODUCTION}

Outbreaks of crown-of-thorns starfishes (COTS) Acanthaster planci L., defined as rapid increases in starfish densities to $>1500$ starfish $\mathrm{km}^{-2}$ (Moran \& De'ath 1992), represent the most significant biological disturbance on tropical coral reefs (Birkeland \& Lucas 1990), resulting in extensive (up to $90 \%$ ) mortality among reef-building and habitat forming corals (Pratchett 2005, Pratchett et al. 2009). A. planci is the principal cause of long-term coral loss at many locations in the Pacific, including Palau, Guam and Fiji (Bruno \& Selig 2007, Pratchett 2010). Extensive coral losses caused by outbreaks of A. planci also have secondary effects on reef fishes (Sano et al. 1987).

Outbreaks of COTS typically end with rapid population declines, though the causes of these rapid declines are largely unknown (Moran et al. 1985, Moran 1986, Pratchett 2005). In Fiji, the rapid disappearance of Acanthaster planci following an extensive outbreak in the 1980s was attributed to disease (Zann et al. 1990). Disease has also been implicated in the mass-mortalities of numerous other echinoderms (Dungan et al. 1982, Lessios et al. 1984, Williams 1986). Pratchett (1999) also demonstrated that tissue removed from sick and dying COTS, collected on the Great Barrier Reef towards the end of an outbreak, can be used to infect other seemingly healthy starfish, indicating that COTS are susceptible to infectious diseases. While there was no attempt to isolate the pathogen involved, Sutton et al. (1988) isolated several potential pathogens, including Vibrio harveyi, V. tubiashi, V. campbellii, Pseudomonas and Moraxella bacteria, in captive A. planci that 
were exhibiting conspicuous signs of disease. However, Pseudomonas and Moraxella were described as normal flora in coral reef seawater around healthy COTS in subtropical Japan (Okinawa) (Reed et al. 1999). In another echinoderm, Vibrio harveyi, $V$. natriegens and $V$. alginolyticus were described as the causal agents of skin ulceration disease in cultivated juveniles of Holothuria scabra (Morgan 2000, Becker et al. 2004). V. anguillarum and Aeromonas salmonicida also induced the bald sea urchin disease of Strongylocentrotus purpuratus (Gilles \& Pearse 1986). These pathogenic vibrios coordinate the expression of certain genes in response to their population density through a quorum sensing mechanism (QS), releasing and detecting signal molecules or autoinducers consisting of $\mathrm{N}$-acyl homoserine lactones (AHLs). These regulatory systems control various functions, including bioluminescence, conjugative plasmid transfer, biofilm formation, antibiotic synthesis, motility and production of virulence factors in animal, plant and human pathogens (Peters et al. 2003, Fangfang et al. 2008, Park et al. 2008).

Vibrios are usually isolated and cultured in microbiology laboratories by the use of thiosulfate-citratebile-sucrose agar (TCBS), which is considered the primary plating medium universally used for the isolation of these bacteria (Kobayashi et al. 1963). This highly selective agar meets the nutritional requirements of Vibrio spp., allowing vibrios to compete with intestinal flora (Baron et al. 1994). TCBS components include yeast extract and bacteriological peptone which provide the nitrogen, vitamins and amino acids. Sodium citrate, sodium thiosulfate and ox bile are selective agents, providing an alkaline $\mathrm{pH}$ to inhibit Gram-positive organisms and suppress coliforms. An increased $\mathrm{pH}$ is used to enhance growth of vibrios, because these organisms are sensitive to acid environments. Sucrose is the fermentable carbohydrate. Sodium chloride stimulates the organism's growth and maintains the osmotic balance of the medium. Sodium thiosulfate is a sulfur source and together with ferric citrate acts as an indicator to detect hydrogen sulfide production. Bromothymol blue and thymol blue are $\mathrm{pH}$ indicators and agar is the solidifying agent.

The purpose of this study was to explore a novel method to control COTS through the injection of TCBS agar. This induces a fatal disease that spreads to in-contact COTS. A secondary aim was to identify naturally occurring bacteria in COTS before and after TCBS injections. Moreover, this study examines whether these potential vibrio pathogens would cause symptoms consistent with natural instances of disease observed previously.

\section{MATERIALS AND METHODS}

\author{
Study sites
}

The study was undertaken during FebruaryDecember 2009 at 2 locations: (1) Lizard Island $\left(14^{\circ} 40^{\prime} \mathrm{S}, 145^{\circ} 27^{\prime} \mathrm{E}\right)$ located in the far northern section of the Great Barrier Reef (GBR; Australia) and (2) Haputo Point, northwest Guam $\left(13^{\circ} 28^{\prime} \mathrm{N}\right.$, $144^{\circ} 40^{\prime} \mathrm{E}$ ), in the Western Pacific Ocean.

\section{COTS collection and maintenance conditions}

A total of 80 COTS were collected from a range of different depths (3 to $15 \mathrm{~m}$ ) and from low- and highdensity populations. Fifty starfish were from Lizard Island and 30 from Guam. A total of 58 starfish were placed in pairs in $68 \mathrm{l}$ plastic aquariums (Nally bins; $64 \mathrm{~cm}$ long $\times 41 \mathrm{~cm}$ wide $\times 40 \mathrm{~cm}$ deep). The other 22 starfish were placed in a large tank $(270 \mathrm{~cm}$ long $\times$ $160 \mathrm{~cm}$ wide $\times 50 \mathrm{~cm}$ deep) with constant water flow and an average temperature of 28 to $30^{\circ} \mathrm{C}$.

\section{Media cultures}

Thiosulfate-Citrate-Bile-Sucrose Agar (TCBS; Oxoid ${ }^{\mathrm{R}}$ ), Nutrient Agar $\left(\mathrm{NA}_{\text {; }}\right.$ Oxoid $\left.{ }^{\mathrm{R}}\right)$ supplemented with $2 \% \mathrm{NaCl}$ and Marine Broth $\left(\mathrm{MB}_{i}\right.$ Difco $\left.^{\mathrm{TM}}\right)$ (detailed formulas shown in Table 1) were used to culture all organisms of potential significance from the starfish and to determine whether these culture media could induce disease in Acanthaster planci. A total of $88 \mathrm{~g}$ of the TCBS agar were added to $1 \mathrm{l}$ of reverse-osmosis purified water, heated with permanent agitation to promote the dissolution of the powder but were not excessively heated or autoclaved. This kept the TCBS media in a liquid state for subsequent injection in COTS. MB and NA were prepared following the manufacturer's instructions. All media were stored at $4^{\circ} \mathrm{C}$.

\section{Culture media experiments}

Five different experiments were carried out.

Expt 1. Nine COTS separated into 3 groups of 3 starfish were used in this experiment. Twelve $\mathrm{ml}$ of each medium were injected to individual COTS with a 21 gauge syringe to determine which media culture induced disease. COTS were individually placed in separate aquaria to observe their behaviour, reac- 
Table 1. Typical components $\left(\mathrm{g}^{-1}\right.$ ) of culture media and their uses. TBCS: thiosulfate-citrate-bile-sucrose agar

\begin{tabular}{|c|c|c|c|c|}
\hline Component & $\begin{array}{l}\text { TCBS } \\
\left(\mathrm{g} \mathrm{l}^{-1}\right)\end{array}$ & $\begin{array}{l}\text { Nutrient agar } \\
\qquad\left(\mathrm{g} \mathrm{l}^{-1}\right)\end{array}$ & $\begin{array}{l}\text { Marine broth } \\
\qquad\left(\mathrm{g} \mathrm{l}^{-1}\right)\end{array}$ & Function \\
\hline Yeast extract & 5 & 2 & 1 & Nitrogen, vitamins, amino acids \\
\hline Peptone & 10 & 5 & 5 & \\
\hline Sodium chloride & 10 & 5 & 19.45 & Stimulates growth \\
\hline Agar & 14 & 15 & & Food additive and solidifying agent \\
\hline Ferric citrate & 1 & & 0.1 & Indicator of hydrogen sulfide \\
\hline Ox bile & 8 & & & $\begin{array}{l}\text { Selective agents, inhibit Gram-positive organisms } \\
\text { and suppress coliforms }\end{array}$ \\
\hline Sodium thiosulfate & 10 & & & \\
\hline Sodium citrate & 10 & & & \\
\hline Sucrose & 20 & & & Carbohydrate \\
\hline Bromothymol blue & 0.04 & & & $\mathrm{pH}$ indicator \\
\hline Thymol blue & 0.04 & & & $\mathrm{pH}$ indicator \\
\hline Lab-Lemco P & & 1 & & Protein extract \\
\hline pH (range) & $8.4-8.8$ & $7.2-7.6$ & $7.4-7.8$ & \\
\hline
\end{tabular}

tions and the latency period of the disease and time to death.

Expt 2. Fifteen COTS injected with TCBS were used in this experiment; separated into 3 groups of 5 starfish and placed in individual aquaria at 3 different temperatures $\left(26,28\right.$ and $30^{\circ} \mathrm{C}$ ) to investigate whether changes in temperature influenced the bacterial ecology, accelerated the presentation of clinical signs and affected time to death.

Expt 3. Eighteen COTS were placed in pairs into Nally bins; one starfish in each tank was injected with $12 \mathrm{ml}$ of TCBS solution to observe whether the disease induced by TCBS injection could be transmitted to the healthy in-contact COTS.

Expt 4. Sixteen COTS located in pairs in 8 aquariums were used in this experiment. Induction of disease through the injection of $12 \mathrm{ml}$ of TCBS was followed by removal of sick COTS to investigate whether diseases continued to progress without the presence of sick COTS. Once the exposed starfish showed the first clinical signs of mucus on the tip of spines and loss of vertical aspect of spines, the injected COTS were removed and $1 \mathrm{ml}$ of water with mucus was collected to measure bacterial density by the dilution and plating method.

Expt 5. A total of 22 COTS were placed in a large tank at the Marine Laboratory University of Guam (UOGML) at $28.7^{\circ} \mathrm{C}$. Two were injected with the TCBS solution to (1) observe whether Guam COTS were susceptible to the disease induced by TCBS injection, (2) determine whether healthy COTS at high densities and in contact would avoid the sick starfish; and (3) investigate whether healthy Guam COTS also become infected with the transmissible disease once they were exposed to sick COTS (outbreak density simulation).

\section{Sample collection and bacterial identification}

Microbiology. In order to culture bacteria for later identification, sterile inoculation loops were used to swab the skin surface, dermal lesions and inside the anus of individual starfish. These samples were then streaked on TCBS and NA with $2 \% \mathrm{NaCl}$ plates and grown for $24 \mathrm{~h}$ at 30 to $32^{\circ} \mathrm{C}$. Individual colonies from these plates were grown in $\mathrm{MB}$ at 30 to $32^{\circ} \mathrm{C}$ with shaking. Bacterial stocks were stored in liquid nitrogen at $-80^{\circ} \mathrm{C}$ in either MB with $30 \%$ (v/v) glycerol or in Microbank ${ }^{\mathrm{TM}}$ cryovials (Pro-Lab Diagnostics) for further identification using PCR.

DNA extraction and PCR. Genomic DNA was extracted from overnight MB cultures of 19 COTS bacterial isolates using the Wizard Genomic DNA Purification Kit (Promega ${ }^{\circledR}$ ) according to the manufacturer's instructions. Identification of isolates at the level of species was carried out on the basis of the $16 \mathrm{~S}$ ribosomal RNA gene following PCR amplification and sequencing of this gene as described by Lane (1991), using the primers $27 \mathrm{f}$ (AGA GTT TGA TCC TGG CTC AG) and 1492r (GGT TAC CTT GTT ACG ACT T). All PCRs were performed in a GENEAMP PCR System 9700 (Perkin Elmer). PCR reactions $(20 \mu \mathrm{l})$ contained $\sim 20 \mathrm{ng} \mathrm{ul}^{-1}$ of genomic DNA, $1 \times$ PCR buffer (Tris-Cl, $\mathrm{KCl},\left(\mathrm{NH}_{4}\right)_{2} \mathrm{SO}_{4}, 1.5 \mathrm{mM} \mathrm{MgCl}_{2} ; \mathrm{pH}$ 8.7) (Qiagen) with a final concentration of $1.5 \mathrm{mM} \mathrm{MgCl}, 0.5 \mu \mathrm{M}$ of each primer, $200 \mu \mathrm{M}$ dNTPs and $0.5 \mathrm{U}$ Taq polymerase (Qiagen). A $5 \mu$ sample of each PCR product was resolved by electrophoresis at $100 \mathrm{~V}$ for $30 \mathrm{~min}$ in $1 \%$ agarose gel, to detect amplicons of the expected sizes and PCR products were sequenced by Macrogen Ltd, Korea. 
Phylogenetic analysis. DNA sequences were assembled using the computer software Sequencher 4.9 (Gene Codes). Sequences were manually corrected, trimmed, and finally compared with those of closest relatives available in the GenBank nucleotide database using the BLASTN search algorithm (Altschul et al. 1990). Subsequently, edited sequences were aligned by Clustal_X (Thompson et al. 1997). Phylogenetic trees based on 16S rRNA sequences were constructed with PAUP v.4.0B10 (Swofford 2003) under the neighbour-joining (NJ) algorithm (Saitou \& Nei 1987). A total of 19 sequence of the isolates under study and 24 publicly available sequences from type strains of species were used to construct the phylogeny. For the analysis, uncorrected 'p' distance and the Kimura 2-parameter correction (Kimura 1980) were tested. Bootstrap support of phylogenies was calculated on 1000 replicates.

\section{RESULTS}

\section{Induction of disease}

Expt 1. TCBS was the only media culture that induced death of COTS $\sim 11.5 \mathrm{~h}$ post-injection at $30^{\circ} \mathrm{C}$. $\mathrm{MB}$ induced signs of disease $5 \mathrm{~h}$ post-injection but COTS recovered after $10 \mathrm{~h}$. NA broth did not lead to the display of significant signs of disease in healthy individuals.

The characteristic clinical signs of the disease showed by all COTS were discoloured and necrotic skin, ulcerations, loss of body turgor, accumulation of colourless mucus on many spines, especially at their tips and loss of spines. Blisters on the dorsal integument broke through the skin surface and resulted in large, open sores that exposed the internal organs. Oedema and reddened digestive tissues, and lysis of connective fibers and the magnesium calcite skeleton were also common and were observed in infected COTS (Fig. 1).

Expt 2. Changes in temperature significantly delayed the presentation of clinical signs of disease and time to death between 25 and 50\%. COTS injected with TCBS and placed at $30^{\circ} \mathrm{C}$ died within 10 to $14 \mathrm{~h}$; at $28^{\circ} \mathrm{C}$ died within 14 to $18 \mathrm{~h}$ and at $26^{\circ} \mathrm{C}$ died within 18 to $24 \mathrm{~h}$ (Fig. 2). A few starfish lasted longer than others.

Expt 3. Successful transmission to healthy COTS was observed. COTS that were injected with TCBS displayed signs of disease and died within $24 \mathrm{~h}$. Incontact COTS showed similar signs of disease and also died within 24 h (Fig. 3). However, 2 in-contact COTS were exposed to high flow currents without direct mucus contact due to pump pressure problems; one displayed rapid recovery and the other was not infected.

Expt 4. COTS exposed for short periods to sick COTS recovered normal spine positions, reduced mucus production and recuperation was observed after $7 \mathrm{~h}$ of solitary confinement. In contrast, COTS with more advanced signs of disease (blisters, open sores) died even when sick TCBS-injected COTS were removed from the aquarium. Increases in bacterial densities ranging between $10^{5}$ and $10^{7}$ colony forming units ( $\mathrm{cfu}) \mathrm{ml}^{-1}$ were observed in these COTS, showing a direct relation with the presentation of disease.

Expt 5. Guam COTS were susceptible to the infectious disease induced by injection of TCBS, and COTS at high densities with open spaces did not avoid sick, in-contact starfish making them more susceptible to disease transmission (Fig. 3). Successful disease transmission was observed and infected starfish died in a similar period compared to those from the GBR (Fig. 3).

\section{Isolates identification}

The 16S rRNA gene was successfully amplified from 19 bacterial isolates. BLASTN searches allowed identification of isolates as Vibrio spp., Photobacterium spp. and Bacillus sp. with 99 to $100 \%$ sequence identities. In the case of Vibrio isolates, phylogenetic analysis based on the 16S rRNA sequences, and not only BLAST searches, was necessary for the identification at species level, due to the high similarities among species for this gene and the presence of multiple unclassified sequences in the databases (Gomez-Gil et al. 2004, Cano-Gómez et al. 2010). For isolates belonging to the $V$. harveyi species group ( $V$. harveyi, $V$. rotiferianus, $V$. campbellii and $V$. owensii) the $16 \mathrm{~S}$ rRNA gene sequence interspecies similarities ranged from 98.9 to $99.6 \%$. The phylogenies offered a more precise identification although low bootstrap support was obtained in numerous nodes (Fig. 4). Strains isolated from sick Acanthaster planci were tentatively identified as $V$. owensii, V. rotiferianus, V. harveyi, V. natriegens, $V$. fortis and Photobacterium eurosenbergii. Strains of Bacillus sp., $V$. fortis, $V$. rotiferianus, $V$. owensii and $P$. eurosenbergii were found in wild healthy animals. Sequences of the 16S rRNA gene were submitted to GenBank (accession nos. HQ44999 to HQ449979; see Fig. 4 for Vibrio spp.). Accession numbers for Bacillus sp. (isolate: Beige, not shown) and Pseudoalteromonas sp. (isolate: Gumar, not shown) are HQ449959 and HQ449967, respectively. 

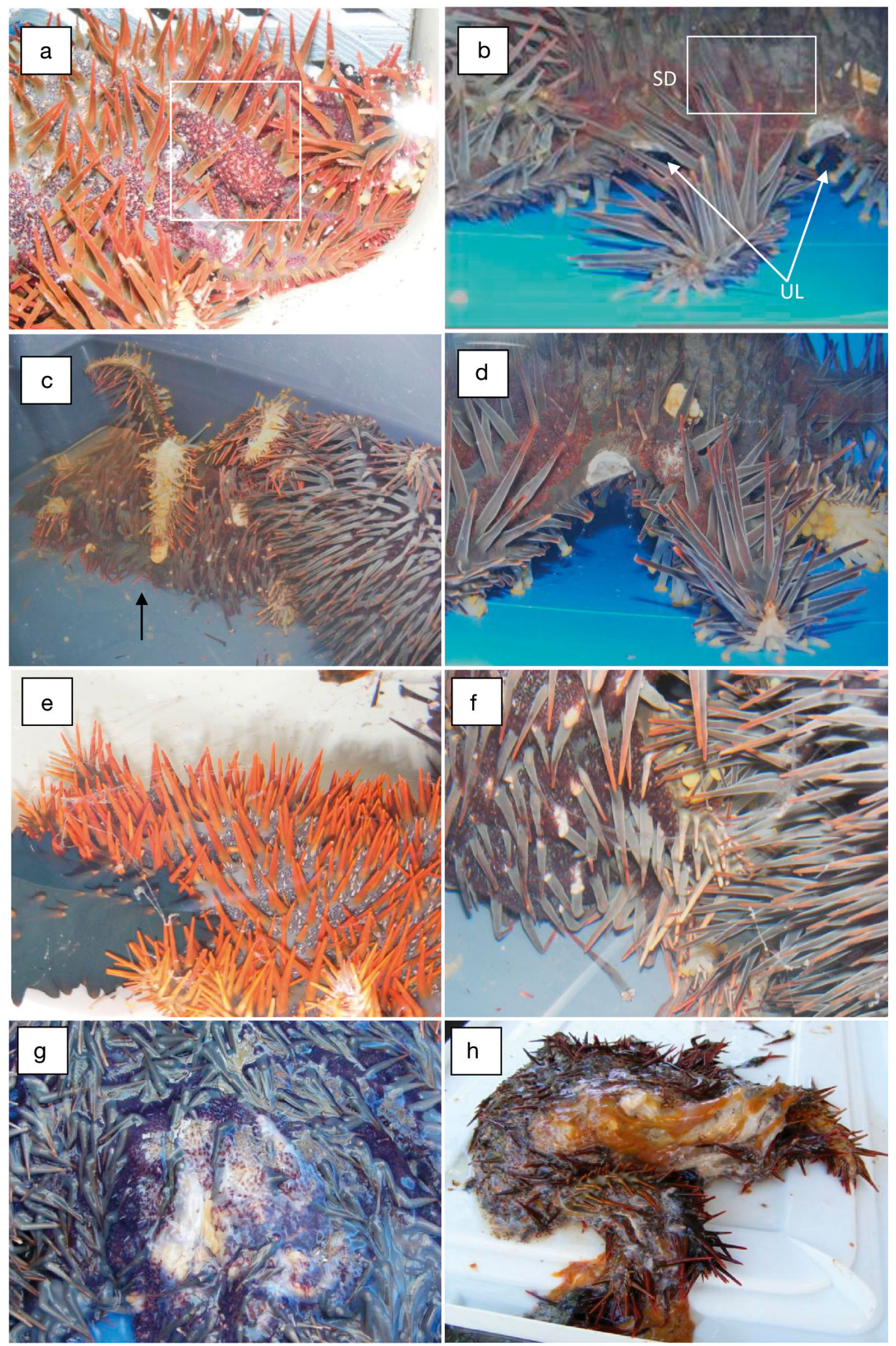

Fig. 1. Acanthaster planci. Clinical signs of disease. (a) Loss of skin turgor, blister formation. (b) Ulcerations (UL, white arrows), changes in colour of skin (SD). (c) Loss of a straight orientation and fall of spines (black arrow). (d) Blisters on dorsal surface, ulcerations and exposure of digestive glands. (e,f) Colourless mucus at the top of the spines. $(g$,h) Destruction of collagen tissues (skin, digestive glands); (H) Death 


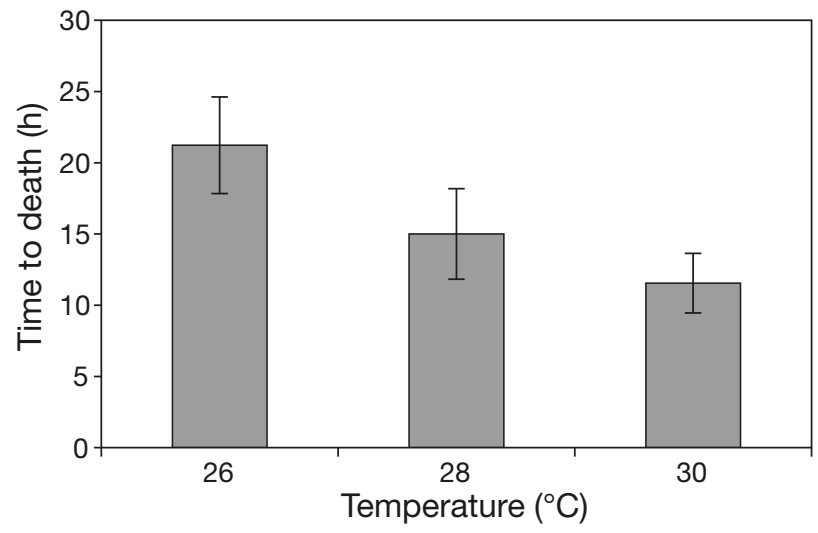

Fig. 2. Acanthaster planci. Time to death of crown-of-thorns starfish (COTS) in relation to variations in water temperature $(\mathrm{n}=5$ COTS per temperature)

\section{DISCUSSION}

\section{Method of action}

Intestinal flora plays an essential role in health, stimulating the immune system, protecting the host from invading pathogenic bacteria and viruses, supporting digestion and assimilating food (Orrhage \& Nord 2000, Guarner \& Malagelada 2003). Interactions of typical intestinal bacteria also contribute to stabilization 'eubiosis' or destabilization 'dysbiosis' of the gastrointestinal tract affecting host homeostasis.

Different mechanisms are used by beneficial bacteria to maintain eubiosis within the gastrointestinal tract: (1) secretion of antibacterial substances such as hydrogen peroxide, organic acids and bacteriocins to reduce the number of viable pathogenic organisms, or decrease of bacterial metabolism and toxin production; (2) competition for nutrients necessary for patho- gen survival; (3) competition with pathogens to prevent their adhesion to the intestine; (4) enhancement of production of defensive molecules in the host such as mucins; and (5) direct uptake or decomposition of organic matter or toxic material produced by pathogenic bacteria (Brook 1999, Liévin et al. 2000, Guarner \& Malagelada 2003). For instance, Jiravanichpaisal et al. (1997) inhibited growth of Vibrio spp., Escherichia. coli and Staphylococcus sp. with Lactobacillus sp. in Penaeus monodon affected by white spot disease. Conversely, blockage and disruption of beneficial bacteria allow rapid growth of pathogens leading to infection. The greater the imbalance between beneficial and pathogenic bacteria, the greater the symptoms. Under certain conditions, gut microflora can be modified by the substrates which they receive, predominantly through the diet (Bird et al. 2000).

The exact mechanisms that initiate disease with TCBS injection have not been identified. Non-bacterial agents such as viruses or allergic reactions cannot be totally excluded. However, observations using scanning electron microscopy (SEM) did not reveal any viruses (Becker et al. 2004). An allergic reaction to chemicals in the TCBS formulation almost certainly does not initiate a transmissible disease that spreads to healthy in-contact COTS. TCBS, nutrient agar and marine broth formulations share most of their main ingredients. However, nutrient agar and marine broth do not induce death in healthy COTS (control). The main difference between these 3 media is that TCBS also contains ox bile, sodium thiosulfate, sodium citrate and sucrose.

Ox bile, sodium thiosulfate and sodium citrate inhibit Gram-positive bacteria and suppress coliforms inducing dysbiosis of the gastrointestinal tract.
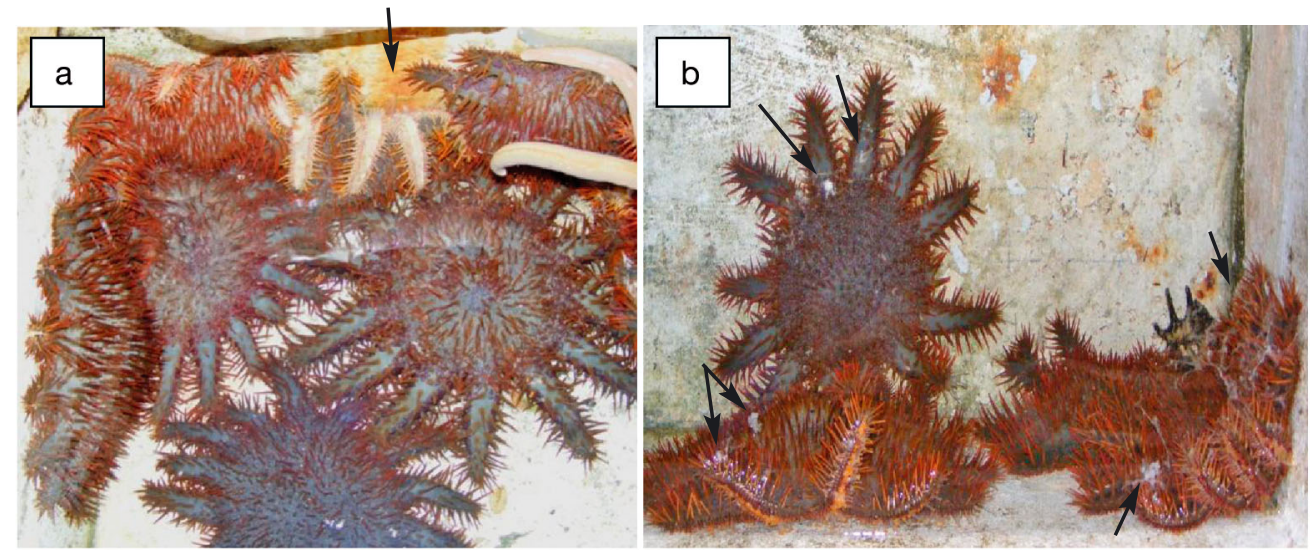

Fig. 3. Acanthaster planci. Disease transmission between in-contact A. planci at high densities. (a) A. planci injected with thiosulfate-citrate-bile-sucrose agar (black arrow) displaying initial signs of disease; there was no avoidance of sick starfish. (b) Infected starfish covered by mucus (black arrows), indicating early signs of successful transmission of disease 


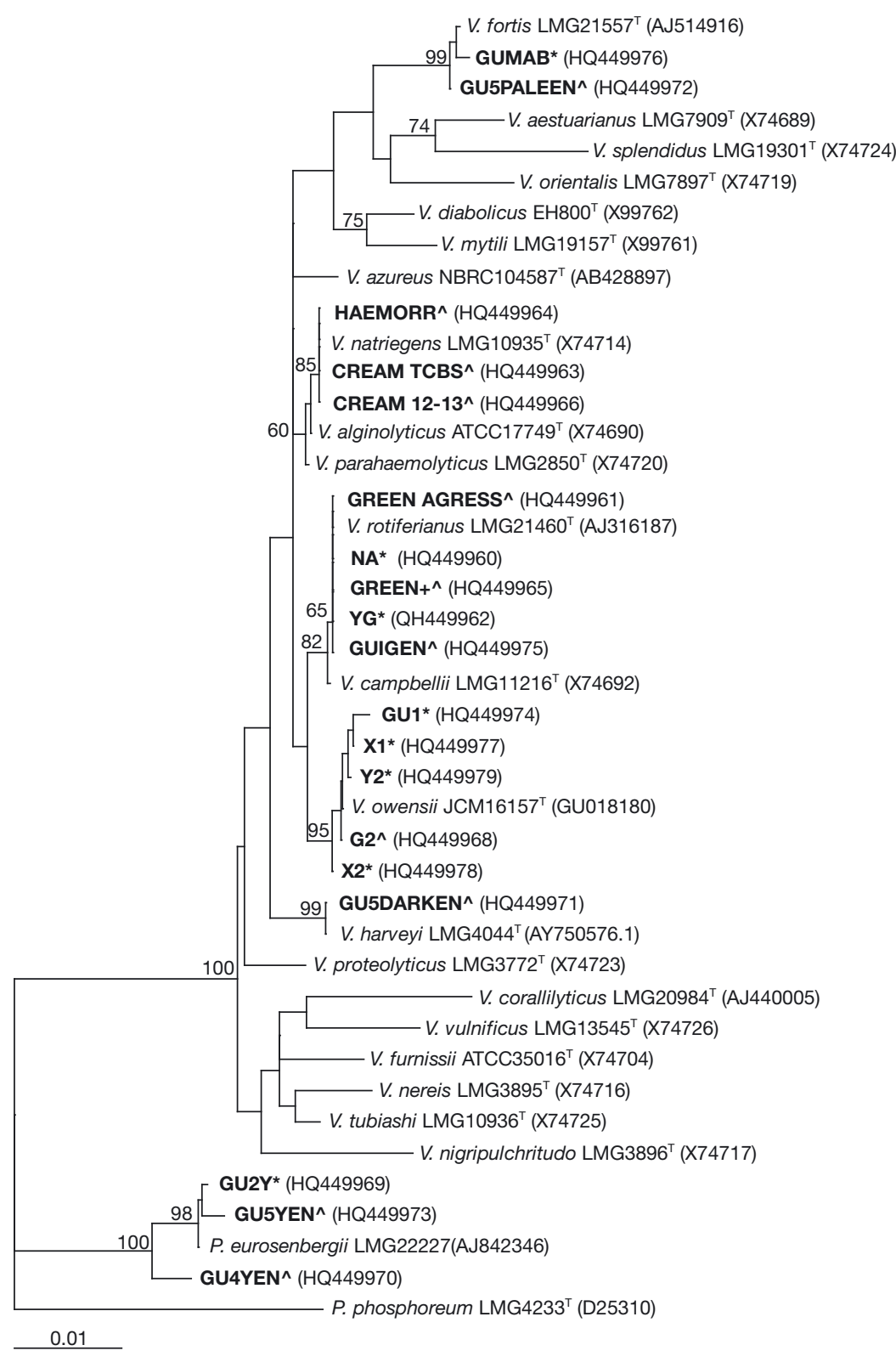

Fig. 4. Vibrio spp. Neighbour-joining phylogenetic analysis of Vibrio isolates from Acanthaster planci, based on partial 16S rRNA gene sequences (1302 nt). GenBank accession numbers are provided in parentheses. Photobacterium phosphoreum LMG $4233^{\mathrm{T}}$ was used as outgroup. Bootstrap support values $>50 \%$ and after 1000 simulations are shown. Bar shows $1 \%$ sequence divergence. 'GU' strains isolated from Guam (USA), *: strains isolated from wild A. planci. ${ }^{\wedge}$ : strains isolated from TCBS-injected moribund A. planci

Pathogenic Vibrio rotiferianus (isolates GREEN+ and GREEN AGRESS) and $V$. natriegens (isolates CREAM TCBS and CREAM 12-13) (Fig. 4) were recovered from mucus of infected COTS that spread over healthy in-contact Acanthaster planci. Vibrio species integrate environmental signalling to modulate behaviour by biasing movements toward more favourable conditions or away from unfavourable environments. Motility and chemotaxis greatly influence the infectivity of vibrios (Butler \& Camilli 2004, Larsen et al. 2004). For example, $V$. anguillarum and $V$. alginolyticus undergo positive chemotaxis to mucus collected from fish skin and intestines (Bordas et al. 1998). V. shiloni, a coral pathogen, migrates towards coral mucus (Banin et al. 2001); V. coralliilyticus exhibits chemotaxis towards the mucus of Pocillopora damicornis (Meron et al. 2009) and $V$. cholerae moves into intestinal mucus (Freter \& O'Brian 1981). Under these conditions and the quorum sensing hypothesis, these migrating vibrios can cause disease in COTS populations by invading incontact individuals as well as enhancing virulence of normal flora through quorum sensing signalling. Vibrios as opportunistic species can evolve and recombine genes under high microbial contact in animal guts or as part of aquatic biofilms, transferring or inducing expression of virulence genes in less or non-pathogenic populations (Thompson et al. 2004).

The features of TCBS coupled with an ideal water temperature, adequate salinity and alkaline $\mathrm{pH}$ stimulate Vibrio growth to high density, which activates their virulence factors via quorum sensing. Once the COTS immune system fails, skin, ulcerations

Sucrose supplements the high metabolism of vibrios, promoting rapid growth. We hypothesize that inhibition of competitive bacteria and increase in vibrio cell density activate the quorum sensing (QS) mechanism of the vibrios, turning on virulence factors (Peters et al. 2003) inducing rapid onset of symptoms followed by death. and exposed organs are colonized by opportunistic bacteria.

Echinoderm body walls consist primarily of collagenous dermis and calcite ossicles. These tissues are known as mutable collagenous tissue (MCT) because they can change stiffness by over an order of magnitude within several seconds. MCT changes are 
accomplished by neurally mediated variation in the cation concentration of the proteoglycan matrix. This determines tensile strength, stiffness and viscosity of the body wall, representing a key mechanism involved in many echinoderm functions such as defense against predators, movement, feeding, immune protection against pathogenic bacteria and others (O'Neill 1989, Wilkie 2002). Vibrios as pathogenic agents disrupt the hydroelectric transport of ions (especially $\mathrm{Na}, \mathrm{K}, \mathrm{Cl}$ and $\mathrm{HCO}_{3}$ ) inducing tissue structural changes and severe damage (Thompson et al. 2006, Khemiss et al. 2009). Disruption of hydroelectric transport of ions affects the normal echinoderm body wall functions and consequently the subcuticular bacteria symbionts (SCB) located between their ectoderm and surface cuticle. SCB were found in all echinoderm classes and play important roles in defense against bacterial infestation in echinoderms (Burnett \& McKenzie 1997). Disruption of transport of ions induced by vibrios at body wall level explains the loss of body turgor (Fig. 1a) and epidermal lesions described in COTS (Fig. 1b,d,g).

\section{Temperature enhancement}

Among the numerous environmental factors that influence Vibrio spp, temperature had a significant effect in this study. A temperature drop of 4 degrees between experiments reduced the induction of disease and time to death between 25 and $50 \%$, similar to findings of Thompson et al. (2006). Nevertheless, warmer temperatures in combination with other physical factors like alkaline $\mathrm{pH}$, plankton blooms, sunlight and UV intensity can also influence bacterial attachment, growth and multiplication in the aquatic environment, increase the rates of induction and propagation of the CTX phage, and promote viability and culturability of vibrios. For instance, $V$. cholerae remains stable in full sunlight in contrast to enteric bacteria such as Escherichia coli, which gives vibrios a clear advantage at tropical latitudes (Mezrioui et al. 1995).

\section{Isolates identification}

For species belonging to the Harveyi clade, identification based on 16S rRNA gene analysis is often imprecise (Vandenberghe et al. 2003, Gomez-Gil et al. 2004). Among the Harveyi clade, species of the Vibrio harveyi group (V. harveyi, V. campbellii, $V$. rotiferianus and $V$. owensii) have almost indistin- guishable phenotypes and genotypes with cases of identical biochemical profiles and $100 \%$ gene sequence identities among different species (GomezGil et al. 2003, Cano-Gómez et al. 2010).

Sequence analysis of the 16S rRNA gene is still essential for bacterial taxonomy (Cohan 2001); however, the resolution power of this molecule is inappropriate in discriminating among closely related species (Kolbert \& Persing 1999, Janda \& Abbott 2007), such as those belonging to the Harveyi clade. In the present study, the resolution power of the 16S rRNA gene for discrimination of Vibrio harveyi, $V$. rotiferianus and $V$. owensii was low with low bootstrap supported tree branches and high inter-species sequence similarities (98.9 to $99.6 \%)$. Precise identification was further obscured by the presence of multiple ambiguous nucleotide positions, scored following the degenerate base code. The effect of these positions was evident especially for the closely related clusters of $V$. owensii and $V$. rotiferianus. These ambiguities are related to the presence of 2 chromosomes in some Vibrio species (Tagomori et al. 2002), responsible for the existence of multiple divergent copies of the 16S rRNA gene in the same bacterial genome. These arguments support ongoing studies performing biochemical tests and analysis of additional genetic markers for a more precise identification of $V$. harveyi-related species associated with COTS.

\section{Control methods}

Attempts to control Acanthaster planci outbreaks either by collection of adult individuals followed by burial ashore, by injections of starfish with toxic chemicals affecting other marine organisms or by placing underwater fences are all expensive and time consuming methods only feasible for small areas. Current control methods are ineffective in either eradicating the coral-feeding starfish or preventing further coral mortality. Biological control of populations through manipulation of predators, parasites or pathogens has not been fully investigated (Sutton et al. 1988). Nevertheless, several authors state that predators do not limit the population density of COTS once they reach outbreak levels (McCallum 1987, Moran 1988). Moreover, there are no reports about significant increases in the densities of the major fish predators of COTS (Williams 1986).

Despite more than 3 decades of research and the commitment of millions of dollars, control methods have been unsuccessful as well as costly, time consuming and difficult to accomplish. For example, 
divers need to inject chemicals into several areas of each starfish to avoid the starfish simply rejecting the single, injected arm and regenerating. Furthermore, spines are sharp and carry haemolytic toxins (saponins). A puncture wound from a spine is intensely painful and causes oedema, erythema and infection of the surrounding areas. Limiting the exposure of divers to spines by having a propagating epizootic would be a boom to safety. The susceptibility of Acanthaster planci to disease could provide an option for controlling population outbreaks. Injection of TCBS culture medium into A. planci induces a rapid fulminating disease that is transmitted to incontact COTS under favourable conditions. Additionally there is no introduction of new pathogens into the environment and it is a rapid and simple procedure with immense economic advantages. However, growth of vibrios enhanced by the TCBS might perhaps have detrimental effects on other reef organisms during a control program. Therefore, further disease dynamics and transmission experiments are warranted, especially in corals, carnivorous fishes and benthic detritus feeders. This is the first part of a series of studies that evaluate whether TCBS injection could be a new tool for management of COTS outbreaks.

Acknowledgements. Funding for this project was provided by the ARC Centre of Excellence for Coral Reef Studies, the Australian Institute of Marine Science (AIMS) and Project AWARE. Field sampling was conducted with kind support and logistic assistance from Lizard Island Research Station and The Marine Laboratory University of Guam.

\section{LITERATURE CITED}

Altschul SF, Gish W, Miller W, Myers EW, Lipman DJ (1990) Basic local alignment search tool. J Mol Biol 215:403-410

Banin E, Israely T, Fine M, Loya Y, Rosenberg E (2001) Role of endosymbiotic zooxanthellae and coral mucus in the adhesion of the coral bleaching pathogen Vibrio shiloi to its host. FEMS Microbiol Lett 199:33-37

Baron EJ, Peterson LR, Finegold SM (1994) Vibrio and related species, Aeromonas, Plesiomonas, Campylobacter, Helicobacter, and others. In: Baron EJ, Peterson LR, Finegold SM (eds) Bailey \& Scott's diagnostic microbiology, 9th edn. Mosby, St. Louis, MO, p 429-434

$>$ Becker P, Gillan D, Lanterbecq D, Jangoux M, Rasolofonirina R, Rakotovao J, Eeckhaut I (2004) The skin ulceration disease in cultivated juveniles of Holothuria scabra (Holothuroidea, Echinodermata). Aquaculture 242:13-30

Bird AR, Brown IL, Topping DL (2000) Starches, resistant starches, the gut microflora and human health. Curr Issues Intest Microbiol 1:25-37

Birkeland C, Lucas J (1990) Acanthaster planci: major management problem of coral reefs. CRC press, Boca Raton, FL
Bordas MA, Balebona MC, Rodriguez-Maroto JM, Borrego JJ, Morinigo MA (1998) Chemotaxis of pathogenic vibrio strains towards mucus surfaces of gilt-head sea bream (Sparus aurata). Appl Environ Microbiol 64:1573-1575

> Brook I (1999) Bacterial interference. Crit Rev Microbiol 25: 155-172

> Bruno JF, Selig ER (2007) Regional decline of coral cover in the Indo-Pacific: timing, extent, and subregional comparisons. PLoS One 2:e711

$>$ Burnett WJ, Mckenzie JD (1997) Subcuticular bacteria from the brittle star Ophiactis balli (Echinodermata: Ophiuroidea) represent a new lineage of extracellular marine symbionts in the subdivision of the class Proteobacteria. Appl Environ Microbiol 63:1721-1724

Butler SM, Camilli A (2004) Both chemotaxis and net motility greatly influence the infectivity of Vibrio cholera. Proc Natl Acad Sci USA 101:5018-5023

Cano-Gómez A, Goulden EF, Owens L, Høj1 L (2010) Vibrio owensii sp. nov, isolated from cultured crustaceans in Australia. FEMS Microbiol Lett 302:175-181

Cohan FM (2001) Bacterial species and speciation. Syst Biol 50:513-524

> Dungan ML, Miller TE, Thompson DA (1982) Catastrophic decline of a top carnivore in the Gulf of California rocky intertidal zone. Science 216:989-991

Freter R, O'Brien PC (1981) Role of chemotaxis in the association of motile bacteria with intestinal mucosa: chemotactic responses of Vibrio cholera and description of motile non-chemotactic mutants. Infect Immun 34: 215-221

Gilles KW, Pearse JS (1986) Disease in sea urchins Strongylocentrotus purpuratus: experimental infection and bacterial virulence. Dis Aquat Org 1:105-114

Gomez-Gil B, Thompson FL, Thompson CC, Swings J (2003) Vibrio rotiferianus sp. nov., isolated from cultures of the rotifer Brachionus plicatilis. Int J Syst Evol Microbiol 53: 239-243

> Gomez-Gil B, Soto-Rodriguez S, García-Gasca A, Roque A, Vázquez-Juárez R, Thompson FL, Swings J (2004) Molecular identification of Vibrio harveyi-related isolates associated with diseased aquatic organisms. Microbiology 150:1769-1777

> Guarner F, Malagelada JR (2003) Gut flora in health and disease. Lancet 361:512-519 (N Am Ed)

> Janda JM, Abbott SL (2007) 16S rRNA gene sequencing for bacterial identification in the diagnostic laboratory: pluses, perils and pitfalls. J Clin Microbiol 45: 2761-2764

Jiravanichpaisal P, Chuaychuwong P, Menasveta P (1997) The use of Lactobacillus sp. as the probiotic bacteria in the giant tiger shrimp (Penaeus monodon Fabricius). In: Borowitzka MA (ed) Abstract of poster session of the 2nd Asian-Pacific Marine Biotechnology conference and 3rd Asia-Pacific conference on algal biotechnology, 7-10 May 1997, Phuket, Thailand. NSTDA, Bangkok, p 16

> Khemiss F, Ahmadi S, Massoudi R, Ghoul-Mazgar S, Safta S, Moshtaghie AA, Saidane D (2009) Effect of in vitro exposure to Vibrio vulnificus on hydroelectrolytic transport and structural changes of sea bream (Sparus aurata L.) intestine. Fish Physiol Biochem 35:541-549

> Kimura M (1980) A simple method for estimating evolutionary rates of base substitutions through comparative studies of nucleotide sequences. J Mol Evol 16:111-120

Kobayashi T, Enomoto S, Sakazaki R, Kuwahara S (1963) A new selective medium for pathogenic vibrios: T.C.B.S. 
agar (modified Nakanishi agar). Nippon Saikingaku Zasshi 18:387-392 (in Japanese with English Abstract)

Kolbert CP, Persing DH (1999) Ribosomal DNA sequencing as a tool for identification of bacterial pathogens. Curr Opin Microbiol 2:299-305

Lane DJ (1991) 16S/23S rRNA sequencing. In: Stackebrandt E, Goodfellow M (eds) Nucleic acid techniques in bacterial systematics. John Wiley \& Sons, Chichester

> Larsen MH, Blackburn N, Larsen JL, Olsen JE (2004) Influences of temperature, salinity, starvation on the motility and chemotactic response of Vibrio anquillarum. Microbiology 150:1283-1290

Lessios HA, Robertson DR, Cubit JD (1984) Spread of Diadema mass mortality through the Caribbean. Science 226:335-337

Liévin V, Peiffer I, Hudault S (2000) Bifidobacterium strains from resident infant human gastrointestinal microflora exert antimicrobial activity. Gut 47:646-652

McCallum HI (1987) Predator regulation of Acanthaster planci. J Theor Biol 127:207-220

Meron D, Efrony R, Wesley RJ, Schaefer AL and others (2009) Role of flagella in virulence of the coral pathogen Vibrio coralliilyticus. Appl Environ Microbiol 75: 5704-5707

> Mezrioui N, Oufdou K, Baleux B (1995) Dynamics of non-O1 Vibrio cholerae and fecal coliforms in experimental stabilization ponds in the arid region of Marrakesh, Morocco, and the effect of sunlight on their experimental survival. Can J Microbiol 41:489-498

Moran PJ (1986) The Acanthaster phenomenon. Oceanogr Mar Biol Annu Rev 24:379-480

Moran P (1988) Crown-of-thorns starfish questions and answers. Australian Institute of Marine Science, Townsville

Moran PJ, De'ath G (1992) Estimates of the abundance of the crown-of-thorns starfish Acanthaster planci in outbreaking and non-outbreaking populations on reefs within the Great Barrier Reef. Mar Biol 113:509-515

Moran PJ, Bradbury RH, Reichelt RE (1985) Mesoscale studies of the crown-of-thorns/coral interaction: a case history from the Great Barrier Reef. Proc 5th Int Coral Reef Symp, Tahiti 5:321-326

Morgan AD (2000) Aspects de la gestion des stocks géniteurs d'holothuries de sable (Echinoderme: Holothurides). La Bêche-de-mer Bulletin de la CPS 13:2-8

O'Neill P (1989) Structure and mechanics of starfish body wall. J Exp Biol 147:53-89

Orrhage K, Nord CE (2000) Bifidobacteria and lactobacilli in human health. Drugs Exp Clin Res 26:95-111

Park SJ, Park SY, Ryu CM, Park SH, Lee JK (2008) The role of AiiA, a quorum-quenching enzyme from Bacillus thuringiensis on the rhizosphere competence. J Microbiol Biotechnol 18:1518-1521

Peters L, König MG, Wright AD, Pukall R, Stackebrandt E, Eberl L, Riedel K (2003) Secondary metabolites of Flustra foliacea and their influence on bacteria. Appl Environ Microbiol 69:3469-3475

Editorial responsibility: David Bruno, Aberdeen, UK
Pratchett MS (1999) An infectious disease in crown-ofthorns starfish on the Great Barrier Reef. Coral Reefs 18: 272

Pratchett MS (2005) Dynamics of an outbreak population of Acanthaster planci at Lizard Island, northern Great Barrier Reef (1995-1999). Coral Reefs 24:453-462

Pratchett MS (2010) Changes in coral assemblages during an outbreak of Acanthaster planci at Lizard Island, northern Great Barrier Reef (1995-1999). Coral Reefs 29: 717-725

Pratchett MS, Schenk TJ, Baine M, Syms C, Baird AH (2009) Selective coral mortality associated with outbreaks of Acanthaster planci L. in Bootless Bay, Papua New Guinea. Mar Environ Res 67:230-236

$>$ Reed KC, Crowell MC, Castro MD, Sloan ML (1999) Skin and soft-tissue infections after injury in the ocean: culture methods and antibiotic therapy for marine bacteria. Mil Med 164:198-201

Saitou N, Nei M (1987) The neighbor-joining method: a new method for reconstructing phylogenetic trees. Mol Biol Evol 4:406-425

Sano M, Shimizu M, Nose Y (1987) Long-term effects of destruction of hermatypic corals by Acanthaster planci infestation on reef fish communities at Iriomote Island, Japan. Mar Ecol Prog Ser 37:191-199

Sutton DC, Trott L, Reichelt JL, Lucas JS (1988) Assessment of bacterial pathogenesis in crown-of-thorns starfish, Acanthaster planci (L.). Proc 6th Int Coral Reef Symp, Townsville 2:171-176

Swofford DL (2003) PAUP* : phylogenetic analysis using parsimony ( ${ }^{*}$ and other methods), version 4.0B10. Sinauer Associates, Sunderland, MA

> Tagomori K, Iida T, Honda T (2002) Comparison of genome structures of vibrios, bacteria possessing two chromosomes. J Bacteriol 184:4351-4358

> Thompson JD, Gibson TJ, Plewniak F, Jeanmougin F, Higgins DG (1997) The Clustal_X Windows interface: flexible strategies for multiple sequence alignment aided by quality analysis tools. Nucleic Acids Res 25:4876-4882

> Thompson FL, Iida T, Swings J (2004) Biodiversity of vibrios. Microbiol Mol Biol Rev 68:403-431

Thompson FL, Austin B, Swings J (2006) The biology of vibrios. ASM Press, Washington, DC

Vandenberghe J, Thompson FL, Gomez-Gil B, Swings J (2003) Phenotypic diversity amongst Vibrio isolates from marine aquaculture systems. Aquaculture 219:9-20

Wilkie IC (2002) Is muscle involved in the mechanical adaptability of echinoderm mutable collagenous tissue? J Exp Biol 205:159-165

Williams D (1986) Temporal variation in the structure of reef slope fish communities (central Great Barrier Reef): short term effects of Acanthaster planci infestation. Mar Ecol Prog Ser 28:157-164

Zann L, Brodie J, Vuki V (1990) History and population dynamics of the COTS starfish Acanthaster planci (L.) in the Suva area, Fiji. Coral Reefs 9:135-144

Submitted: January 31, 2011; Accepted: July 22, 2011

Proofs received from author(s): October 29, 2011 